KOVÁCH IMRE - KRISTÓF LUCA - SZABÓ ANDREA ${ }^{1}$

TÁRSADALMI INTEGRÁCIÓ, DEZINTEGRÁCIÓ ÉS TÁRSADALMI RÉTEGZŐDÉS

Dol: $10.18030 /$ socio.hu.2015.3.63

\title{
ABSZTRAKT
}

Tanulmányunk célja, hogy bemutassa, miben különbözik, és hogyan kapcsolódik össze a társadalom integrációja, illetve dezintegrációja a társadalom rétegződésével, egyenlőtlenségeivel. Ehhez elsőként összefoglaljuk a társadalmi rétegződéskutatásokat az utóbbi néhány évtizedben ért legnagyobb kihívásokat és az azokra adott válaszkísérleteket. Ezután ezeket a kísérleteket a hazai szakirodalom kritikai összefoglalásával helyezzük el magyar társadalmi kontextusban. A társadalmi integráció és dezintegráció fogalmainak definiálása után az integráció és a társadalmi rétegződés egymáshoz való viszonyát - és ezzel összefüggésben integrációs kutatásunk két fő célkitúzését határozzuk meg: a hagyományos rétegződési paradigmához képest új szempontok szerint is azonosítható csoportok, rétegek, osztályok leírását és képzését, valamint azoknak az integrációs/dezintegrációs mechanizmusoknak a feltárását, amelyek magyarázzák az e csoportok közötti különbségeket.

Kulcsszavak: társadalmi integráció, dezintegráció, rétegződés

\section{SOCIAL INTEGRATION, DISINTEGRATION AND SOCIAL STRATIFICATION}

\section{ABSTRACT}

The aim of our paper is to present the difference and the relationship between social integration/ disintegration and social stratification. First, we summarize the major challenges to the study of social stratification and the responses given by scholars in the past few decades. Then, we contextualize these developments with a critical overview of the Hungarian social stratification literature. After defining social integration and disintegration and their relationship with social stratification, we identify the two main goals of our research project: (i) the identification and description of social groups and strata based on novel aspects compared to the old stratification paradigm, (ii) the description of integrative/disintegrative mechanisms explaining differences among these groups.

Keywords: social integration, disintegration, social stratification

1 Kovách Imre és Kristóf Luca az MTA Társadalomtudományi Kutatóközpont Szociológiai Intézet, Szabó Andrea az 1 MTA Társadalomtudományi Kutatóközpont Politikatudományi Intézet munkatársai. 
KOVÁCH IMRE - KRISTÓF LUCA - SZABÓ ANDREA

\section{TÁRSADALMI INTEGRÁCIÓ, DEZINTEGRÁCIÓ ÉS TÁRSADALMI RÉTEGZŐDÉS}

Tanulmányunk² célja, hogy bemutassa, miben különbözik, és hogyan kapcsolódik össze a társadalom integrációja, illetve dezintegrációja a társadalom rétegződésével, egyenlőtlenségeivel. A dolgozat a magyar társadalom integrációjáról és dezintegrációjáról szóló kutatás azon bevezető, elméleti munkáinak a sorába tartozik, amelyek célja a kvalitatív és kvantitatív elemzések fogalmi megalapozása. Magának a témának a fogalmi tisztázása különös jelentőségű az integrációkutatás számára. A két közelítésmód egyrészt kiegészíti egymást, hiszen az integrációs mechanizmusok (Dupcsik-Szabari 2015) ismerete vezethet el a társadalmi egyenlőtlenség okainak a megértéséhez. Másrészt, az integráció- és rétegződéskutatás ab ovo társadalmi csoportok jellemzőinek az elemzése. Az integráció/dezintegráció elemzés nem váltja fel vagy helyettesíti a rétegek kutatását, de a hasonló integrációs és dezintegrációs értékek, normák, minták és mechanizmusok szerint cselekvők csoportjai, valamint a foglalkozás, iskolázottság és hasonló dimenziók mentén leírt társadalmi rétegek között számos átfedés és ellentmondás is lehetséges. Harmadrészt, az integráció és dezintegráció kutatás célja, hogy a rétegződéskutatások érvényességének elhalványulása miatt olyan fogalmi és empirikus elemzési módokat dolgozzon ki, amelyekkel a magyar társadalom szerveződésével kapcsolatos kutatás megújítható.

Tanulmányunk szerkezete a következő: az első részben felvázoljuk a társadalmi rétegződéskutatásokat az utóbbi néhány évtizedben ért legnagyobb kihívásokat és az azokra adott válaszkísérleteket. Ezután ezeket a kísérleteket a hazai szakirodalom kritikai összefoglalásával helyezzük el magyar társadalmi kontextusban. A tanulmány második részében a társadalmi integráció és dezintegráció fogalmi meghatározását végezzük el, majd az integráció és a társadalmi rétegződés egymáshoz való viszonyát - és ezzel összefüggésben integrációs kutatásunk két fő célkitǔzését - határozzuk meg.

\section{„KULTURÁLIS FORDULAT" ÉS A RÉTEGZŐDÉSKUTATÁSOK. A VÁLASZ NÉLKÜLI KIHÍVÁS}

Közel egy évtizede született tanulmányainkban (Kovách-Kuczi-Jókuthy 2006, Kuczi-Kovách-Kristóf 2006) egyértelmúen állást foglaltunk amellett, hogy a társadalmi különbségek kutatásában paradigmaváltás szükséges. Az egyenlőtelenségek kutatásának hagyományos paradigmája, az egyének munkaerő-piaci pozícióját kifejező, foglalkozások alapján létrehozott munkajelleg csoportok és azok 1990 után módosított változatai alkalmasnak bizonyultak ugyan a rendszerváltást követő átalakulás egyes tendenciáinak leírására, viszont az elmúlt negyedszázad társadalmi változásai és az ezekhez kapcsolódó új intellektuális feladatok következtében a hagyományos paradigma újragondolása szükséges. Nem ismételjük meg az idézett tanulmányok eredményeit és következtetéseit, amelyek részletesebben kifejtették a paradigmaváltás szükségessége mellett szóló érveket, a paradigma fennmaradásának tudománytörténeti, intézményi, hatalmi és társadalomtörténeti hátterét. Ezek lényege, hogy a hagyományos, foglalkozás alapú csoportosítások használata vagy azok kibővítése a tőketulaj- 
donlás különbségeivel csak korlátozottan alkalmas arra, hogy megérthetővé és elemezhetővé váljanak az ezredforduló közeli magyar társadalom egyenlőtlenségeinek tendenciái és okai. A társadalomkutatás „kulturális fordulatának" megközelítésmódjai, a fogyasztás, az élmény- és rizikótársadalom nézőpontjai, a társadalmi nem, a hálózati társadalom problematikája, a média és a politika csoportképző szerepe nem épültek be szervesen a rétegződés-modellekbe. A fogyasztás összetevőivel vagy például a nemek társadalmi helyzetének különbségeivel foglalkozó munkákban változatlanul a munka világában elfoglalt pozíció és esetleg a tôketulajdon vagy annak hiánya alapján létrehozott egyenlőtlenség-modell(ek) jelenti(k) a független változót, míg a „posztmodern” témák és területek mintegy függő változókként tételeződnek.

A múlt század '80-as éveitől a hagyományos rétegződés és osztálymodellek erodálódása miatt új szempontok érvényesítése indult meg a releváns társadalmi különbségek kutatására változatlanul nyitott társadalomtudományokban. Ulrich Beck némi iróniával így jellemezte ezt az állapotot: „A valóság búcsút mondott az össztársadalmi rétegződési modellekben gondolkodó egyenlötlenségkutatásnak, elillant elöle, és ez a döntő oka annak, hogy a szociológiai egyenlötlenség-kutatás egyre inkább a társadalmi irrelevancia 'duzzogójába' kényszerül." (1997: 425)

Az egyenlőtlenség kutatások megújítására több közismert kísérlet is történt. Stefan Hradil (1995) egy hagyományos, többdimenziós rétegződésmodell felől indulva, a német SINUS-intézet empirikus vizsgálatait felhasználva jutott arra a következtetésre, hogy sem az osztálymodellek, sem a rétegződésmodellek nem írják le kielégítően az 1980-as évek nyugat-német társadalmának egyenlőtlenségeit. Az osztály, illetve rend fogalmai helyett a miliő az a csoport, mely a társadalmi valóság leírására jóval inkább használható. Hradil modelljében a társadalmi pozíció három szintjét különböztette meg: a strukturális életfeltételeket (egyenlőtlenségeket), a miliőspecifikus életvilágokat és az egyéni élethelyzeteket. Empirikusan a modell nyolc miliőcsoportból állt: a felső és felső-középrétegek konzervatív, technokrata-liberális és alternatív miliőre bomlottak, a középrétegek miliői a kispolgári, a felemelkedés-orientált és a hedonista miliő voltak, az alsó-közép és alsó rétegekben pedig a tradicionális, illetve a tradíciók nélküli munkásmiliő volt megtalálható. ${ }^{3}$

A miliő-alapú irányzatot a kilencvenes években Gerhard Schulze vitte tovább. Híres könyvében (Élménytársadalom, Schulze 1992) a társadalmi csoportok között a két kemény szociológiai jellemzővel, az életkorral (nemzedékhez való tartozással) és a képzettséggel leírt személyes stílus a jellegadó különbség. Az életkor és a képzettség tengelyei mentén Schulze öt miliőcsoportot különít el. Ezek közül kettő fiatal(os), három pedig a társadalom idősebb tagjait jellemzi, az életkori határsáv valahol a harmincötödik és negyvenötödik év között húzódik. A miliőstruktúra specialitása, hogy más rétegződésmodellekkel szemben „életlen”: egy egyén két miliőnek is része lehet egyszerre. További fontos, Schulze által is hangsúlyozott különbség, hogy - ellentétben a jövedelem, vagy más makrováltozók alapján kreált társadalmi nagycsoportokkal - a miliők tagjai észlelik saját hovatartozásukat; jellemzőjük, hogy többet érintkeznek egymással, mint más miliők tagjaival.

Az életstílus- és miliő-kutatás párhuzamosan fejlődött ki az individualizációs megközelítéssel az elmélet és az empíria kölcsönös egymásra hatásának eredményeképpen. Az individualizációs hipotézis talán legna-

3 A SINUS-intézet (SINUS Sociovision) továbbra is készít miliőleírást a német társadalomról. Az aktuális, 10 miliőből álló modell megtalálható: http://www.sinus-institut.de/en/solutions/sinus-milieus.html. 
gyobb hatású megfogalmazója a fent idézett Ulrich Beck (1997), aki szerint a jövedelmi és oktatási viszonyok javulása a 20. század második felének nyugati társadalmaiban az egyenlőtlenségek csökkenése nélkül is társadalmi felvonóhatással, és egyben az egyéni életesélyek pluralizálódásával járt. Főként a középső társadalmi rétegekben a kulturális gyakorlatok, a fogyasztás és az életstílus legtöbb eleme nem feltétlenül kötődik többé a külső létfeltételekhez és az erős közösségi normákhoz, hanem egyéni döntésekkel szabadon alakítható. Az újonnan létrejövő társadalmi csoportok az osztályoknál, rétegeknél képlékenyebbek, könnyebben változnak, nem feltétlenül egész életre szólók.

Az életstílus- és miliőkutatásokat megalapozó elméletek lassanként klasszikus teóriává válva bekerültek a 21. századi szociológia tankönyvekbe és szöveggyưjteményekbe, elméleti népszerűségük azonban nagyobb, mint empirikus felhasználtságuk a rétegződéskutatásokban. Bizonyosan „átszivárgott” azonban ezekből a modellekből a társadalmi rétegződés kutatásába az individuális fogyasztás szempontjának figyelembe vétele, ami a társadalmi státusszal foglalkozó elméleti és kutatási hagyomány (ha úgy tetszik, a weberi hagyomány) folytatóitól korábban sem állt távol.

A neoweberiánus osztályelemzés talán legismertebb modellje az EGP-séma (Erikson-GoldthorpePortocarero 1979). Goldthorpe és munkatársai foglalkozási pozíciójuk alapján sorolták hét osztályba az egyéneket, különbséget téve a foglalkoztatók és az alkalmazottak, illetve utóbbiakon belül a munkaszerződés alapján vagy a szolgáltatói típusú viszonyban dolgozók között. Az EGP séma mindmáig széles körben használatos, standard nemzetközi összehasonlításokra is alkalmas modell, melyet azonban számos kritika ért.

Ennek jegyében elsősorban a brit szociológiában történtek erős kísérletek az osztályelemzés megújítására (Crompton 1993, Crompton et al. 2000). Az osztályelemzés és a stratifikációs kutatások eltérő módszereiról kitüntetett viták folytak (Crompton 1993). Az osztályelemzéseket a '70-es években például a feminista teoretikusok támadták erősen. Szerintük az osztály és a nemek problematikáját nem lehet az egyéneket és csoportokat munkaerő-piaci pozíció alapján osztályozó modellekkel elemezni. A kritikák következtében a következő három területen próbálkoztak az osztályelemzés megújításával: teoretikusan megalapozott, nagy adatbázisokon végzett, makroszintű kapcsolati elemzések, osztályok képződésének társadalomtörténeti összefüggéseit vizsgáló elemzések (Lash-Urry 1997, McNnall-Levine-Fantasia 1991), Bourdieu munkáinak hatására felerősödő elemzések az osztályok kulturális meghatározóiról és újratermeléséről, és ezekkel összefüggésben a fogyasztás szociológiájáról. Crompton összegzése szerint a társadalmi osztály értelmezése és a stratifikáció empirikus elemzései a szociológiai elméletek (pozitivizmus és a normatív funkcionalizmus bírálata, a neomarxizmus, a filozófiai „realizmus”, posztmodern) fejlődésének hatására alakultak át, és kevéssé követtek egyfajta belső logikát. A munkát és a foglalkoztatást egyre kevésbé tekintették az osztályokhoz tartozás meghatározó tényezőjének, következésképp az osztály a társadalmi egyenlőtlenséget megjelenítő leíró kategóriaként elvesztette jelentőségét, és sokak szemében történeti fogalommá változott.

Crompton és a brit kutatók egy nagyobb csoportja szerint azonban az osztály fogalma és a társadalmi rétegződés modelljei változatlanul érvényesek a társadalmi egyenlőtlenségek kutatásában. Egy 2000-ben megjelent antológia bevezetőjében Crompton és Scott kifejtette, hogy az „osztály” fogalma túl nagy és széteső társadalmi alakzatok (a középosztály, felső osztály, alsó osztály), státuscsoportok és presztízssorrendek le- 
írására szolgált. A stratifikációs és az osztályelemzések a '90-es évekre a gazdag kutatási gyakorlat ellenére egyfajta válságba jutottak, amelyen Crompton és Scott szerint a korábbi módszerek meghaladásával, illetve a posztmodern megközelítések kulturális és identitáskérdéseket központba állító alkalmazásával lehet túljutni. Az osztályelemzés megújításához az osztály és réteg multi-dimenzionális kategóriaként történő elismerését és az egydimenziós kategorizálások elkerülését szorgalmazták. Crompton egy későbbi tanulmánya (2008) pedig arra mutatott rá, hogy a foglalkozásnak mint az osztályhelyzet egyetlen mérőszámának használata figyelmen kívül hagyja azokat a bonyolultabb utakat, melyeken át az osztályok szimbolikusan és kulturálisan megteremtődnek. Az EGP-séma kritikusainak érvei között az is szerepel, hogy az osztályelemzést érdemes lenne kibővíteni a termelés, a fogyasztás és az elosztás folyamatainak elemzésével. Az alkalmazott módszerek és teóriák pluralizmusának szükségességét hangsúlyozták még, mert szerintük az egyéni cselekvéseknek a társadalomszerkezethez kapcsolódását egyetlen kitüntetett magyarázó elv szerint megérteni nem lehet.

Devine és Savage (2000) további szempontokat kínál az osztály- és rétegződéskutatás megújitásához. A foglalkozások aggregálásával létrehozott osztályok, rétegek és csoportok mellett vagy helyett Devine és Savage szerint az osztály és a rétegződés fogalmainak politikai gazdaságtanra alapozott kritikai elméletét kellene kidolgozni, amely újraértelmezhetővé tenné az osztály, a társadalmi nem és az etnikum kapcsolatát. A második helyen a rétegszerkezet és a rétegkultúra elkülönített vagy egymás függvényeiként történő kutatása és a köztük levő interakciók vizsgálata helyett a kulturális folyamatok gazdasági-társadalmi gyakorlatokba ágyazottságának az elemzését ajánlották.

Az ezredforduló után a brit osztályelemzés Crompton korábbi szerzőtársaihoz köthető (Savage-WardeDevine 2005, Savage et al. 2013) új iránya, a kulturális osztályelemzésnek (Atkinson 2010) is nevezett irányzat alakult ki, amely elméleti keretét Bourdieu klasszikus múvében, a La Distinction-ban (1984) találta meg. Bourdieu-nél a társadalmi osztály nem csak gazdasági, hanem a társadalmi reprodukció és a kulturális megkülönböztetések komplex rendszerében kiformálódó jelenség. A brit kulturális osztályelemzés esetében a három jól ismert bourdieu-i tőkefajta, a gazdasági, a kulturális és a társadalmi tőke dimenzióinak méréséből kiformálódó társadalmi osztályszerkezet modelljéhez való visszalépés történik. A Nagy-Britanniában nagy visszhangot - és kemény kritikákat - kiváltó Great British Class Survey (Savage et al. 2013) a három tőkedimenzió alapján hét osztályt (elit, megalapozott középosztály, új, tehetős munkások, technikai szakértők, tradicionális munkásosztály, felemelkedő szolgáltató osztály és a prekariátus, azaz a bizonytalan léthelyzetúek) különített el. Ebben a modellben a gazdasági tőkét a jövedelem és a lakás értéke, a kulturális tőkét a kultúrafogyasztás két mutatója (a hagyományos magaskultúra fogyasztásában való részvétel, és az új, főként az internethez és különféle közösségi tevékenységekhez köthető 'emerging' kulturális fogyasztás) mérte. A társadalmi tőke két mutatója közül az egyik a gyenge kötések diverzitására, a másik pedig azok társadalmi presztízsére utalt. Azaz, a mennyiségi összetevő azt mutatta, hogy a megkérdezett hányféle foglalkozású embert ismer, a minőségi pedig azoknak a társadalmi presztízsét, akiket ismer, és akiktől segítséget is kérhet. A modellben olyan alapvető szociodemográfiai változók, mint az iskolázottság és a foglalkozás nem voltak csoportképző tényezők, csupán a három tőkefajta alapján létrejövő osztályok jellemzésében volt szerepük. Az életstílus- és miliőkutatásokban nagy szerepet játszó életkor pedig egyáltalán nem hangsúlyos a kulturális osztálykutatásban, bár a létrejövő osztályok között vannak generációs különbségek, például a tradicionális munkásosztály versus felemelkedő szolgáltató osztály esetében. 
A foglalkozásalapú rétegződésmodell leváltására vagy kiegészítésére tett kísérletek a fogyasztási, kulturális és individualizációs tematikákkal folyamatosan jelen voltak az elmúlt évtizedek társadalomtudományi munkáiban, de a „kulturális fordulat” kihívásaira és ösztönzésére válaszként nem született konszenzussal elfogadott új társadalmi egyenlőtlenség modell.

\section{A MAGYAR RÉTEGZŐDÉSKUTATÁSOK MEGÚJÍTÁSI KÍSÉRLETEI \\ (TŐKEVISZONYOK, KULTÚRA, FOGYASZTÁS, ÉLETSTÍLUS)}

Az életstílus, a fogyasztás, a kulturális témák a 20. század utolsó két évtizedében a magyar kutatásokban is felértékelődtek, mindez ugyanakkor nem hozott magával döntő változást a hazai rétegződés-vizsgálatokban. Utasi Ágnes (1984) már a '80-as évek elején, a rétegződésmodell vizsgálat adataira építve komplex, sokdimenziós életstílus-csoportok jelenlétét mutatta ki a magyar társadalomban. A kulturális aktivitás, lakberendezés, lakáskultúra, tárgyi környezet, táplálkozás, ruházkodás, testápolás, kapcsolatrendszer, pénzgazdálkodás, családi szokások, rekreációs tevékenységek indexei alapján kialakított tipológiájában tíz életstílus-csoportot különböztetett meg. Az elit és az intellektuális csoport alatt három felső-középosztálybeli csoport: a családorientált, a felső mintakövető és a tárgyorientált helyezkedett el. Az alsó-középrétegbe a második gazdasággal kompenzáló, a kapcsolatgazdag és a kapcsolatszegény csoport tartozott. A két alsó csoport a robotoló és a többszörösen hátrányos helyzetű elnevezést kapta. Az életstílus különbségekre nagy hatással volt a lakóhely, az iskolai végzettség és a származás. Az egyéni döntések, személyes ízlés szerepe csak erős korlátokkal tudott érvényre jutni.

A '90-es években a TÁRKI kutatói folytatták a fogyasztási mintázatok vizsgálatát. Fábián Zoltán és szerzőtársai (Fábián-Róbert-Szívós 1998) a jövedelmi helyzet, a vagyon, a megtakarítások és a tartós fogyasztási cikkek birtoklása alapján képeztek státuszcsoportokat. A fogyasztásnak inkább mennyiségi mintsem tartalmi, ízlésbeli elemeit vizsgáló kutatás nyolc státuszcsoportot különített el (jómódú, fogyasztáscentrikus, megtakarításcentrikus, vagyonos fogyasztó, vagyonfelélő, kis vagyonú fogyasztó, deprivált és szegény).

Fábián és szerzőtársai két évvel későbbi tanulmánya (Fábián-Kolosi-Róbert 2000) az anyagi mellett már a kulturális fogyasztással is foglalkozott. A három vizsgált dimenzió a lakásvagyon, az anyagi fogyasztás (tartós fogyasztási cikkek, szolgáltatások igénybevétele) és a kulturális fogyasztás (főként szabadidő-eltöltési szokások) volt. Ezúttal a következő hat csoportot határozták meg: elit, jómódú, szabadidő-orientált, felhalmozó, jó lakású deprivált, deprivált szegény. A csoportok között fogyasztás tekintetében nagyobb volt a távolság, mint a hagyományos szocio-demográfiai mutatók szerint. A társadalom középső rétegeiben a hagyományos mutatók szerint a szabadidő-orientált és a felhalmozó csoport gyakorlatilag azonos státuszú, viszont fogyasztási szokásaik merőben eltérőek.

Hasonló megközelítést használt Bukodi Erzsébet (2006) is a 2000. évi KSH Életmód - Időmérleg vizsgálat adatainak feldolgozásakor. Fogyasztási csoportjai szintén az anyagi életvitel, a szabadidős/kulturális aktivitás és a lakáshasználat jellemzői alapján épültek fel, bár a konkrét indikátorok eltértek a TÁRKI adatainak alapján meghatározottaktól. ${ }^{4}$ Bukodi fogyasztási tipológiájában szintén jól láthatóan megjelenik a vertikális és a horizontális

4 Az anyagi életvitel komponensei közé a tartós javak, a vagyoni elemek, a megtakarítások (illetve eladósodottság), a vásárlási, fogyasztási szokások, az üdülés, a lakás-komponensbe a lakókörnyezet, a lakás nagysága és minősége, a szabadidős/kulturális fogyasztásba pedig az írott kultúrához való viszony, az otthonon kívül fogyasztott magaskultúra, a társas szabadidő, az otthoni 
dimenzió is. A középrétegeken belül a hasonló státuszú felhalmozás-orientált, illetve szabadidő-orientált csoportok fogyasztási gyakorlatai és ízlése szerint térnek el egymástól. Ugyanez állapítható meg a kisegzisztenciák két csoportjáról is. Maga a szerző azonban azt hangsúlyozza, hogy az életstílus-tipológia alapvetően hierarchikus, vertikális elrendezettséget mutat. A fogyasztói csoportokhoz való tartozásban nagy szerepet játszik az életkor, illetve még inkább az életciklus: a szabadidő-orientált csoportokban a fiatalok, az egyedülállók, a gyermektelenek, míg a felhalmozás-orientált csoportokban inkább a gyermekes családok felülreprezentáltak.

Csite András és szerzőtársai (Csite-Kovách-Kristóf 2006) fogyasztói miliők létrehozáshoz médiafogyasztási, szabadidő-eltöltési szokásokat és érdeklődési területeket vizsgáltak. E dimenziók alapján 1998-ban öt, 2004-ben pedig hét fogyasztói miliőt lehetett elkülöníteni. 1998-ban a felső két miliő a klasszikus magaskultúra miliője és az újságolvasó miliő nevet kapta. E kettő alatti társadalmi státuszban különült el a férfi, a női és a fiatal miliő. 2004-ben a felsőbb rétegek egy technokrata elitből, valamint egy balliberális és egy jobbos fogyasztói miliőből álltak (ez utóbbi kettő hasonló státuszú, ám eltérő attitűdjeik következtében eltérő médiafogyasztású csoport). A férfi, a női és a fiatal miliő mellett megjelent egy bulvár miliő is.

Fontos azonban megjegyezni, hogy a kimutatott horizontális különbségek mellett a megkérdezettek csaknem egyharmadának fogyasztása és szabadidős aktivitása csekély, fogyasztói miliőhöz nem tartoznak, státuszuk a fogyasztói miliők alatti, és semmiképp sem részei a fogyasztói társadalomnak. Ez a kutatás, és a korábban említett fogyasztáskutatások egyaránt megkérdőjelezik tehát, hogy a tanulmányunk első részében bemutatott individualizáció- és életstílus alapú megközelítések alkalmazhatóak-e egyáltalán - és ha igen, milyen mértékben - a magyar társadalom vizsgálatakor.

A többdimenziós rétegződésmodellek, amelyeknek a legismertebb megjelenései Kolosi Tamás (1987, 2000) „tagolt társadalom” és „terhes babapiskóta” leírásai, erőteljes kísérletet tesznek a foglalkozási alapú besorolások mellett 5-7 elemzési szempont alkalmazására a rétegek meghatározásában. A létrehozott csoportosítás(ok) azonban annyira összetettek és tartalmi értelemben mechanikusak, hogy azonosításuk közel lehetetlen. ${ }^{5}$ Kolosi maga is szembesül az azonosítás nehézségeivel, és a konkrét társadalmi helyzetek és folyamatok elemzéséhez és megjelenítéséhez a foglalkozási csoportokat használja, különösen A terhes babapiskóta oldalain.

A társadalmi újratermelés rendjének változásai közül a tőkeviszonyok hatását Ferge Zsuzsa illesztette be a legkövetkezetesebben a rétegképző dimenziók közé. Új modellje az osztály kategóriáját emeli be (és/vagy vissza) az egyenlőtlenségek leírásába. Ferge a statikus struktúraleírások dinamizálását a struktúra és a cselekvés kettős rendszerének leírásával közelítette meg. Az elemzés egyik, jelen kutatásunk számára is irányadó hozadéka, Ferge (2010) kritikája az EGP modellről és bármilyen más modellről, amely nem számol a tőkeviszonyok különbségeivel a társadalmi különbségek leírásakor. Az új rétegződésmodellben a munkajelleg-csoportokat az

szabadidő és a fizikai aktivitás elemei kerültek bele. E dimenziók alapján tíz fogyasztói csoport alakult ki: a konzisztensen magas státuszúak, a konzisztens felső középréteg, a fogyasztásorientált felső középréteg, a felhalmozás-orientált középréteg, a szabadidő-orientált középréteg, a jó lakású kisegzisztenciák, a szabadidő-orientált kisegzisztenciák, a jó lakású szegények, a konzisztensen szegények és a leszakadók.

5 Az ezredfordulón a státuszcsoportok a következő elnevezéseket kapták: felső középosztály, magas jövedelmű, rossz lakású csoport, magas státusú, alsó közép jövedelmú csoport, munkáselit (formálódó középosztály), kulturális középosztály, alsó középosztály, jó lakású alsó csoport, jó jövedelmú alsó csoport, lecsúszók és visszakapaszkodók, depriváltak (Kolosi 2000). 
osztályok váltják fel. Hat osztályt ír le a tőkeviszonyok és a foglalkozási viszonyok alapján. ${ }^{6}$

A hagyományos rétegződéskutatás témáiról szellemükben nemzetközi szinten is értékes munkák születtek az utóbbi években is például a származás, iskola végzettség, jövedelem összefüggéseiről (Kolosi-Keller 2012), az egyenlőtlenséggel kapcsolatos attitűdökről (Medgyesi 2012) a társadalomszerkezetről (Kolosi-Keller 2010), a magyar társadalom meritokratikus vagy piaci jellegéről (Bukodi-Goldthorpe 2012), a rétegekről és osztályokról (Róbert 2013). E klasszikus egyenlőtlenség témák elemzéséhez nem volt igazán szükség a hagyományos rétegződéskutatás szemléletmódjának és módszereinek megújítására.

Az újraértelmezés igénye a társadalomstatisztikával összefüggő munkákban jelentkezett. Huszár Ákos egyértelmúen az osztály kategória érvényessége mellett érvel. Elismeri az osztály alapú elemzés kritikáinak bizonyos fajta jogosságát, azonban tanulmányok sorával egy új osztályelemzést kíván megalapozni (Huszár 2012, 2013a-c). Az új osztályelemzés alapjának a munkaerő-piaci pozíciót (a foglalkozást) fogadja el, és később keltezett írásaiban a foglalkozási osztályszerkezet kategóriáját használja (Huszár 2013a-c). A kategória alapja a társadalmi tagozódás graduális jellegének kifejezése, a rétegződés modellek leíró-dimenzionális voltával szemben az elméleti-genetikus megközelítés, és végső jellemzőként az, hogy az osztályok gazdasági alapúak. Az egyének helyzetét a társadalomban a Huszár által elemzett (és elfogadott) osztályelemzések szerint továbbra is a társadalom strukturális kényszerei határozzák meg. Az osztályelemzés a rétegződésmodellekkel szemben a hierarchikus kategorizálás mellett képes horizontális viszonyrendszert is kifejezni. Az osztályelméletek a strukturális kényszerek valamilyen elméletéből kiindulva alkotnak osztályozó kategóriákat. Huszár (2013c) kísérletet tesz egy normatív, funkcionalista struktúramodell elméleti alapjainak a felvázolására. A vázolt modell és a dolgozatokban egyelőre inkább jelzésértékú adathasználat arra mutat, hogy Huszár törekvései inkább a stratifikációs ortodoxia egyfajta megújított folytatásának az irányába mutatnak.

A magyar társadalomtudományban a kulturális osztálykutatás kevéssé jelent meg, noha az EGP-séma máig használatos, főként a KSH kutatóinak körében (Bukodi et al. 2005, Bukodi 2006). Utasi Ágnes harminc évvel ezelőtti vizsgálata (Utasi 1984) óta a kapcsolati erőforrásokra sem fordítottak kellő figyelmet a rétegződés kutatói. Róbert Péter és szerzőtársai (előkészületben) azonban nemrégiben megkísérelték a fentebb bemutatott brit osztályfelmérés (Savage et. al 2013) adaptálását a magyar társadalomra. A gazdasági, a kulturális és a társadalmi tőke indikátorainak kisebb módosításával a kutatók a következő nyolc osztályt határozták meg: elit, felső középosztály, yuppik (feltörekvő fiatalok), vidéki értelmiség, kádári kisember, sodródók, munkások, leszakadtak. Ebben a tipológiában is erős vertikális hierarchia figyelhető meg, némi horizontális dimenzióval az életkori és a lakóhelyi különbségeknek köszönhetően. Ugyanakkor, a lakóhely típusa az egyik legerősebb vertikális egyenlőtlenség: a felső három osztály tagjai körében igen erősen felülreprezentáltak a Budapesten és a nagyvárosokban élők.

A nemzetközi és a hazai kulturális és egyéb fogyasztásra, az életstílusra vonatkozó eredmények sem

6 A felső osztályhoz a nagytőkések, nagyvállalkozók, a tehetősebb szabadfoglalkozásúak, a felső gazdasági vezetők és menedzserek tartoznak, a felső középosztály a stabil kisvállalkozókból és középvállalkozókból és a stabil alkalmazotti státuszúakból áll, a középosztályhoz a kis tőkével rendelkező önfoglalkoztatók, és a felsőfokú végzettséggel nem rendelkező stabil alkalmazottak tartoznak, az alsó középosztály a kényszervállalkozók, és a stabil, legális alkalmazással bíró szakképzetlenek, az alsó osztály a bizonytalan helyzetű kényszervállalkozók, az alkalmi munkások, a feketemunkások és a kirekesztettek. Végül a vegyes összetételú, és a hierarchikus osztályozásba nehezen beilleszthető munkásosztály szerepel Ferge rétegződés modelljében. 
vezettek a rétegződés és stratifikációs kutatások, illetve az osztályelemzések elfogadott megújitáshoz. Ennek egyik okát a középrétegesedés visszafogottságában látjuk, aminek a következménye, hogy a társadalom alsó szegmenseiben a posztmodern megközelítések nehezen értelmezhetőek. Az integráció és dezintegráció az irodalomban és közvélekedésben elsősorban a leszakadás, kirekesztődés vonatkozásában használatos. Mindez a tömeges szegénység miatt egyrészt érthető, másrészt nehézségeket okoz a társadalom minden szintjén és szegmensében érvényes és értelmezhető integráltság/dezintegráltság, illetve a hátrányokat elszenvedő csoportok társadalmi állapotait leíró inklúzió, kirekesztés, leszakadás, underclass fogalmak összemosódása miatt.

\section{EGYBECSÚSZÓ FOGALMAK}

A dezintegráció fogalmával együtt, ugyanakkor nem teljesen azonos jelentéstartalommal használt fogalom a társadalmi kirekesztődés (a társadalmi kirekesztődésről részletesen lásd (Szalai 2012, 2013 Sen 2003, Walker 2006 és Ferge 2007). Szelényi és Ladányi (2004) elsősorban a roma lakosságot érintő, kirekesztő folyamatok vizsgálatához az underclass fogalmának használatát javasolja, megállapítva, hogy a kapitalizmus rendszerváltás utáni Magyarországon kialakult variánsa egy „új szegénységet” termel ki, amely hosszabb távú és több dimenziós ahhoz képest, ami az államszocializmusban létezett. Megnyilvánulási formája legalább háromszintű és összekapcsolódó, egymásra épülő kirekesztési struktúra, ami leginkább a lakóhelyi, az iskolarendszeri, illetve a munkaerő-piaci kirekesztésben érhető tetten.

Megnehezíti az integrációs/dezintegrációs, valamint a stratifikációs logika és fogalmak elkülönítését, hogy különösen a társadalom alsó csoportjait tekintve vannak olyan makroszociológiai folyamatok és tényezők, amelyek különösen fontosak az integrációs/dezintegrációs folyamatok, de a rétegződés szempontjaiból is. Ezen konvertálható tőkefajták (Bourdieu 1984, 1999) egyike az iskolarendszer és ezzel párhuzamosan az iskolai teljesítmény, valamint a munkaerő-piaci viszonyok és - a társadalom többsége számára - ezzel szoros korrelációban lévő jövedelem-egyenlőtlenségek.

A szakirodalomban ma már közhelynek számít, hogy az iskola legfontosabb feladata ugyan az lenne, hogy megpróbálja kiegyenlíteni a családi háttérből adódó tagadhatatlanul meglévő különbségeket, azonban a legtöbb vizsgálat arra utal, hogy ezen elvárásoknak csak nagyon kevés ország iskolarendszere tud megfelelni (Esping-Andersen 2006). A magyar közoktatási rendszer nem hogy nem felel meg ezen elvárásoknak, hanem szélsőségesen felerősíti az otthonról hozott társadalmi különbségeket, a gazdasági és leginkább a kulturális tőke egyenlőtlenségeit. A magyar iskolarendszer tehát nem integrál, hanem a szegregáció következtében dezintegrál. ${ }^{7}$ Az iskolai szegregáció tetten érhető a települések között ugyanúgy, mint egyes településen belül (Erőss 2012). Ferge Zsuzsa szerint a magyar iskola „társadalmi küldetését, a gyerekek összességének, és kivált a

7 A PISA2012 felvétel adatai megerősítette azt az egyébként már a 2000-es, első vizsgálatnál rögzített tényt, hogy „Magyarországon az oktatási rendszer eredménytelennek bizonyul a szociokulturális eredetü hátrányokkal szemben, a tudásszerzés családi otthoni környezetből fakadó egyenlőtlenségeit nem sikerül pedagógiai hatásokkal kellőképpen enyhíteni. A mérés nemzetközi kontextusa azt is megvilágítja, hogy hazánk az OECD-átlagnál alacsonyabb átlageredményt az OECD-átlagnál szignifikánsan nagyobb családi háttérből fakadó egyenlőtlenségek mellett érte el." (PISA2012:70) A PISA vizsgálat ugyanis azt mutatta, hogy mindhárom vizsgált kompetencia (matematika, szövegértés, természettudomány) terén a magyar fiatalok önmagukhoz és az OECD-átlaghoz képest is rontottak 2009-es eredményeiken. Ennek hátterében a magyar iskolarendszer rendkívül szelektív jellege áll. Nemzetközi összehasonlításban is drámai a magyar iskolák szegregációja, a homogén társadalmi összetételre való - sikeres - törekvés. 
rosszul indulóknak a "jövőre való felkészítését "romló szinten teljesíti." (2005:14) A magyar iskolarendszerben megtalálható dezintegrativ folyamatok bizonyítéka az iskolák roma tanulókkal szembeni erőteljes diszkriminációja is. Szalai Júlia (2012) kutatásából kiderül, hogy a cigány gyermekek iskolai osztályzatokban megmutatkozó teljesítményértékelései drámaian alacsonyabbak, mint a többségi gyermekeké. Kertesi Gábor és Kézdi Gábor (2009) az általános iskolai szegregációt vizsgáló tanulmányában rámutat, hogy a teljesítményértékelés eltérő mértéke nem pusztán a hátrányosabb társadalmi helyzetből, hanem az ahhoz még hozzáadódó etnikai megkülönböztetésből is fakad. A fentivel összefüggésben az iskolarendszer kifejezetten dezintegratív folyamata a korai iskolaelhagyás viszonylag magas aránya. ${ }^{8}$ További adalék az iskolarendszer rétegződést és integrációt/ dezintegrációt is befolyásoló hatásához, hogy a hazai felsőoktatásban mindössze 1-2\% azon fiatalok aránya, akiknek mindkét szülője legfeljebb alapfokú végzettséggel bír (Szabó 2012:31).

Ferge Zsuzsa 1990-ben megjelent, integrációval és dezintegrációval foglalkozó cikkében a dezintegrációs folyamatok közül először a munkanélküliség problematikáját emelte ki, jelezve, hogy a kialakuló kapitalizmus viszonyai között a munkaerőpiacról való (tartós) kiszorulás markáns szegmentációval jár együtt (a szerző egyenesen egy úffajta kasztosodást vizionál). A rendszerváltást követően a hazai munkaerőpiac rapid összeomlásáról, mindmáig tartó szerkezeti problémáiról, valamint a 2008/2009-es pénzügyi-gazdasági válság munkaerőpiacot érintő negatív következményeiről alapos, több szempontú elemzések születtek az elmúlt években (lásd Laky 1996, Gazsó-Laki-Pitti 2008, Laki 2009, Messing 2012 és Szabó 2013 ez irányú munkáit). Ezekből az írásokból, elemzésekből az derül ki, hogy a rendszerváltást követően néhány év alatt megszűnt legalább 1 millió munkahely hiánya okozza a legjelentősebb, szinte megoldhatatlannak tűnő problémát Magyarországon. ${ }^{9}$ A 2013 -as magyarországi aktivitási ráta uniós összehasonlításban az ötödik legalacsonyabb volt, ugyanakkor a 2014. évi munkaerő-piaci folyamatok, az állami közfoglalkoztatás kiteljesedése okán, az aktivitási ráta emelkedését és ezzel párhuzamosan a munkanélküliség csökkenését vetítik előre. A statisztikákban kimutatható javulás ellenére a tartósan, azaz legalább egy éve vagy annál hosszabb ideje munkanélküliek aránya 49,5\%, amely alig különbözik a 2013. évi mutatótól (50,4\%) (KSH 2015a:60). A munkanélküliség átlagos időtartama ugyanakkor nemhogy nem csökkent 2013-ról 2014-re, hanem folyamatosan növekszik: egy év alatt 17,9 hónapról 18,5 hónapra emelkedett (KSH 2015b: 3). Aki tehát kiszorul a munkaerőpiacról, az jelen állás szerint nemigen talál viszszautat. A legfeljebb alapfokú végzettségűek foglalkoztatási aránya továbbra is alacsony, 2014-re vonatkozóan 25,9\%. Ezzel párhuzamosan körükben a munkanélküliségi ráta is magas: 18,6\%, amely a nemzetgazdasági ráta

8 A korai iskolaelhagyók olyan 18-24 éves fiatalok, akiknek nincs sem szakmunkásvégzettsége, sem érettségije, és a megelőző négy hétben nem vettek részt semmilyen oktatási, képzési formában. A korai iskolaelhagyás mutatója azért növekvő fontosságú, mert „egy olyan réteg nagyságát becsüli meg, akiknél kockázatos, hogy a munkaerő-piaci és társadalmi integrációjuk egyáltalán megtörténik, és nagy - növekvő - eséllyel maradnak egész életük során a társadalom peremén, szociális ellátásra szorulva." (Mártonfi 2013, 2014:38) Az Eurostat legutolsó, 2014-ben közölt adatai szerint a közép-kelet-európai térségben a magyarországinál kedvezőtlenebb mutatója csak Romániának és Bulgáriának van. A V4 országok eredményei nagyságrendekkel jobbak a magyarnál.

91989 és 1993 között a munkahelyek több mint negyede megszúnt (Laky 1996). A trend aztán néhány évig még folytatódott, majd némi korrekció volt érzékelhető az évtized végén, azonban a durván 3,7 milliós „mélyponthoz” képest számottevő változás nem állott be a 2000-es évek elejére sem, így a foglalkoztatottság tartósan alacsony szintje állandósult Magyarországon (Gazsó-Laki 1998, 2004, Gazsó-Laki-Pitti 2008, Szabó 2013). Az alacsony foglalkoztatottság és aktivitás ráadásul tartósan 6 százalék feletti munkanélküliségi rátával párosult. A munkaerőpiacon kialakult dezintegrációs szituáció négy csoportot érintett az átlagosnál erőteljesebben: a legfiatalabbakat, a legidősebbeket, valamint a legalacsonyabb iskolai végzettséggel rendelkezőket és részben ezzel összefüggésben a romákat. 
több mint kétszerese (KSH 2015a 58). Kedvezőtlen a 15-24 évesek foglalkoztatási és munkanélküliségi adatai is. 2014-ben, a korcsoportba tartozók foglalkoztatási aránya 23,5\%, munkanélküliségi rátája pedig 20,4\% volt (KSH 2015a: 59-60). ${ }^{10}$

A társadalmi dezintegrációs folyamatok talán legsürübben épp a jövedelmi szegénységgel összefüggő jelenségek kapcsán érhetők tetten. A magyarországi szegénységi arányok becsléséről a KSH, valamint az Eurostat hivatalos statisztikái mellett a Tárki jelentései is rendelkezésre állnak. Az Eurostat adatai szerint 2000 és 2013 között növekedett azok aránya, akik szegénységi küszöb alatti jövedelemmel rendelkeznek. Ez a küszöb a szabadon elkölthető medián jövedelem 60\%-a. Az adatok azt is jelzik, hogy a szegénység dinamikusan növekedése 2010 óta figyelhető meg: két év alatt 2 százalékponttal nőtt az arány. Ami igazán kedvezőtlen mutató, hogy a legfiatalabbak, azaz a 18 éven aluliak körében a legmagasabb a szegénységi ráta (közel 10 százalékponttal magasabb, mint a teljes népességé), ráadásul 2010-hez képest e téren is inkább növekedésről beszélhetünk. A szakirodalom szerint a gyermekkori szegénység különösen aggasztó jelenség, mert az a gyermek, aki fiatalon szegény, felnőve is nagy valószínűséggel szegény szülő lesz (Esping-Andersen 2006: 53), a szegénységben élő gyermekek ráadásul felnőtt korban sokkal valószínúbben fognak különböző lelki és egészségügyi problémákkal küszködni (Walker 2006). Uniós összehasonlításban a teljes magyar népességre vonatkoztatható adatok nem kiemelkedően kedvezőtlenek, az Európai Unió 27 tagországának átlagánál kissé alacsonyabbak, ugyanakkor - Görögországot kivéve - egyetlen másik ország esetében sem fordult elő, hogy a szegénységi ráta dinamikusan, évről-évre növekedjen az utóbbi években. A fiatalkorúak szegénységét illetően pedig a magyar adatok az alsó harmadban helyezkednek el. A helyzetet tovább árnyalja, ha nemcsak az életkort, hanem az iskolázottságot is figyelembe vesszük. Az Eurostat összehasonlító adatai szerint a legalacsonyabb iskolai végzettségúek (legfeljebb szakiskolát végzettek) körében a 2005. évi 17,1\%-ról 2013-ra 26,5\%-ra nőtt a jövedelemszegénység úgy, hogy 2010-ben e mutató 19,9\%-on állt. ${ }^{11}$

A fenti elemzés alapján nagy biztonsággal lehet körülírni azokat a társadalmi csoportokat Magyarországon, amelyekre a dezintegrációs folyamatok leginkább illenek. Három egymással összefonódó, több szálon kapcsolódó réteget érdemes kiemelni: a munkanélkülieket, a jövedelemszegényeket és a romákat. A brit osztályfelmérés fentebb már hivatkozott magyar adaptációja (Róbert et al. 2014) ugyanis épp azt mutatta ki, hogy a Bourdieu-i tőkefajták operacionalizálása alapján létrehozott társadalmi rétegeken belül az ún. „leszakadtak”

10 A versenyszférával szemben a foglalkoztatottság emelkedése gyakorlatilag a közfoglalkoztatás egyre növekvő arányának köszönhető, ennek tudományos megítélése azonban meglehetősen vegyes (Bonoli 2013: 21-22, Messing 2012: 216, Koltai-Kulinyi 2013: 50, Szabó 2013: 80). Összességében a közfoglalkoztatás önmagában biztosan nem elegendő a munkaerőpiacról tartósan kiszorult társadalmi csoportok hosszú távú rendszerszintű integrációjára. A közfoglalkoztatás ideiglenes megoldás, amely egy adott közösségben - különösen, ha verseny alakul ki a kevés hely megszerzéséért - inkább rontja, mint javítja a társadalmi kohéziót, ugyanakkor előnye, hogy a foglalkoztatás időszakára bár rendkívül szerény, de kiszámítható jövedelmet biztosít a résztvevők számára.

11 A jövedelem-egyenlőtlenségek társadalmi szintű változását pontosan nyomon lehet követni a Tárki Monitor Jelentései alapján. A jövedelmi szegénységben élők profilja a következő: „...tíz szegénységben elő személy közül négy a gyermekkorát, vagy fiatalsá gát éli, a tíz személyböl mindössze egy nyugdijas korú. Tíz szegényböl három roma, és maximum egyikük fövárosi. A szegénységben élők közel fele községben él, majdnem ugyanennyien pedig vidéki városokban. A szegénységben élők fele olyan háztartásban él, ahol a háztartásfö inaktív vagy munkanélküli" (Gábos-Szívós-Tátrai 2013: 43). Érdemes egyébként megemlíteni, hogy a Tárki 2014-es Monitor Jelentése európai összehasonlításban is vizsgálta a jövedelmi szegénység kockázatát. Becslésük szerint a szegénység mértéke 2014-ben az európai átlaggal megegyező, az új tagországok átlagánál valamivel kedvezőbb volt (Szívós-Tóth 2015:46). 
csoportját leginkább ők alkotják. A magyar társadalom számosságában legnagyobb csoportja (23\%) tartozik ide. ${ }^{12}$ Már az apáik is hasonló jellemzőkkel bírtak: azaz e réteg újratermeli önmagát. ${ }^{13} \mathrm{~A}$ Ladányi és Szelényi által a '90-es évek folyamait összegző tanulmányában leírt folyamatok a 2000-es években hatványozottan jelentkeznek a Róberték által „leszakadtaknak”, Szelényiék által „underclassnak” nevezett társadalmi rétegen belül.

\section{INTEGRÁCIÓ, DEZINTEGRÁCIÓ ÉS TÁRSADALMI RÉTEGZŐDÉS}

De mi adja az értelmét és jelentőségét annak, hogy a társadalmi integráció és dezintegráció kutatásakor kiemelten foglalkozzunk az egyenlőtlenségek témájával? Kutatásunk azt az alapkérdést járja körül, hogy minden érzékelhető, és egyre súlyosabbnak tűnő konfliktus és probléma ellenére is, hogyan lehetséges társadalmunk múködése és egyben maradása. Ferge Zsuzsa munkássága kezdetétől fogva a társadalmi integráció pozitiv és negatív jelenségeit vizsgálja. Tanulmányunk szempontjából két, egymásra reflektáló múvére hívjuk fel a figyelmet. 1990-ben, a rendszerváltás hajnalán jelenik meg az az írása, amely számba veszi azokat a folyamatokat, amelyek ugyan többnyire a Kádár-korszakban erednek, de a Magyarországon kialakuló kapitalizmusvariáns hatására felgyorsulni látszottak 1989/1990 fordulóján. Ebben az írásában Ferge Luhmann, Habermas, de leginkább Herbert Gans alapján fogalmazza meg a dezintegráció fogalmát. Úgy véli, hogy a dezintegráció a társadalmi újratermelési folyamatok zavara; amikor az intézmények alig múködnek, az élet objektív feltételei megnehezülnek, a szabályok érvényüket vesztik, és normák nélküli bizonytalan lét uralkodik el. „A tradíciók elutasítása révén a társadalmi azonosság tudat... elvész, és ezzel sajátos vákuumhelyzet teremtődik.” (Ferge 1990: 5) Ferge, Gans értelmezését elfogadva, a dezintegrálódást objektíve negativ jelenségként fogja fel, amely ab ovo együtt jár a szegregációval és a szegmentált társadalommal. 2010-ben jelent meg a Társadalmi áramlatok és egyéni szerepek címú könyve, amelyben részletesen elemzi mindazokat a folyamatokat, amelyeket 20 évvel korábban éppen csak felvillantott. Ferge továbbra is a normák, ezen belül is a közös normák, közösségi, társadalmi elfogadottságát, elterjedését érti integráció alatt a Lockwood és Habermas által felállított/kidolgozott rendszer-integráció - társadalmi integráció fogalmi duál keretrendszerébe ágyazva.

A 2000-es évek második felében a hazai társadalomtudomány több meghatározó szereplője fordult újra az integráció és dezintegráció általános problematikája felé. Mintha az újkapitalizmus és a létező demokrácia ekkorra élte volna fel korábban felhalmozott tartalékait, és a 2008/2009-ben kibontakozó pénzügyi és gazdasági

12 Anyagi, jövedelmi, vagyoni helyzetük rendkívül kedvezőtlen, 34\%-uk legfeljebb 90 ezer forintos háztartási nettó jövedelemmel rendelkezik, lakásértékük a legalacsonyabb. 93\%-uknak semmiféle megtakarítása nincs, viszont körükben a legnagyobb azok aránya, akik tartoznak a villany, gáz vagy víz számlájukkal, adósságuk van a rokonok illetve más magánszemélyek felé (a bankok felé viszont ők tartoznak a legkisebb arányban, nem hitelképesek). Hátrányos helyzetük abból is adódik, hogy kapcsolatszegények, segítséget másoktól nemigen remélhetnek. Jelentős körükben a szakképzetlenek aránya: ha dolgoznak, fizikai vagy mezőgazdasági munkát végeznek, de leginkább munkanélküliek, közfoglalkoztatottak, segélyezettek, és magas körükben a rokkantak, illetve az öregségi nyugdíjasok aránya. 39\%-uk legfeljebb 8 osztályt végzett, további 28\%-uk pedig szakiskolát, szakmunkásképzőt. Ezzel is összefüggésben áll, hogy kultúrafogyasztásuk szinte elhanyagolható mértékű. Egyáltalán nem fogyasztják a magas kultúra termékeit, nem látogatják ezek intézményeit, de az ún. újkultúra (internethez kötődő kultúra) fogyasztásuk is jóval átlagon aluli.

13 A „leszakadtakhoz” tartozó réteg tagjainak közel 60\%-a olyan családban élt, ahol az apa legfeljebb 8 osztályt végzett, körükben a legmagasabb a szakképzetlen fizikai és a mezőgazdasági fizikai munkás apák aránya (közel 50\%). A leszakadtak körében szignifikánsan magas az önmagukat romaként meghatározó válaszadók aránya. Túlnyomó többségük, mintegy kétharmaduk kistelepülésen, egyéb városban vagy községben él. Összességében, deprivált helyzetükkel nagyjából tisztában vannak: a legnagyobb arányban érzik úgy, hogy szüleik nemzedékéhez képest mostanában nehezebb magasabbra kerülni a társadalomban. 
válság nyomán ekkorra kristályosodtak volna ki a magyarországi rendszer egyre súlyosbodó zavarai. Jelen kutatáshoz kapcsolódik a Társadalmi integráció a jelenkori Magyarországon című kötet, mely 27 tanulmányának majd mindegyike igyekszik valamilyen integrációs és/vagy dezintegrációs definíciót alkotni, többnyire eltérő szóhasználatú, mégis egy irányba mutató tartalommal. A Kovách-Kristóf szerzőpáros (2012: 30) a durkheimi tradíciókra építve társadalmi integráció alatt olyan módokat és eszközöket ért, amelyek révén a társadalom tagjai egymásra hatnak, kapcsolatot tartanak, megerősítik és elfogadják összetartozásukat egy közösségen belül. Hajdu Gábor (2012: 45) értelmezésében a dezintegráció a társadalom tagjai közötti bizalom- és szolidaritáshiány, normasértés és alacsony együttmúködési szint. Végül Kapitány Ágnes és Kapitány Gábor (2012: 83) az integrációt egyfajta kölcsönhatásként fogják fel, olyan interakcióként, amelynek végeredménye egy egységes, összehangolt rendszerré válás és az „Egésszel” való identifikálódás. A fentebbi definíciókat összegző és a további kutatást megalapozó elméleti tanulmány pedig így fogalmaz: „Társadalmi integráció alatt értjük, amikor az egyén vagy intézmény (cselekvő, ágens) kooperál egy társadalmi csoporttal vagy kollektivitással úgy, hogy »bizonyos mértékben elfogadja annak értékeit, normáit, szabályait stb. Egy integrált társadalomban az intézmények, normák és szabályok mindenki számára legitim, elfogadható módon jelennek meg. Vagyis, egy "jólı integrált társadalomban az azt alkotó elemek összekapcsolódása, kooperációja ismert és elfogadott." (Dupcsik-Szabari 2015, kiemelések az eredetiben)

A dezintegráció fogalmának egymondatos, mindenki által elfogadott meghatározása éppoly nehéz feladat, mint az integrációé. A dezintegráció fogalmának meghatározása a szakirodalomban ráadásul kétféleképpen történik. Egyes szerzők csak integrációs definíciót adnak, így ezt kell az olvasónak „átfordítania”, negatív előjellel ellátnia, és akkor kapja meg a dezintegráció mechanikus értelmezését, míg más szerzők igyekeznek önálló fogalmat alkotni. Az is nehezíti a tájékozódást, hogy az integráció és dezintegráció általánosabb problematikája periodikusan tér vissza a szakirodalomban: vannak olyan időszakok, amikor különös érdeklődés övezi, más időszakokban inkább az egyes dezintegrált makrocsoportokkal (szegények, kisebbségek), illetve a dezintegrációt előidéző vagy abból következő folyamatokkal (szegénység, egyenlőtlenségek) foglalkoznak a társadalomtudósok. Végül, a harmadik nehézség a fogalom meghatározása kapcsán annak jelentős inflálódása. Az integráció és ezzel párhuzamosan a dezintegráció fogalma az idők folyamán egy általánosan elterjedt, a köznyelvi szóhasználat részévé vált kifejezéssé vált, amelynek univerzalisztikus tartalmat és értelmet tulajdonítanak, és amelyet szinte minden társadalmi konstrukcióra alkalmaznak.

Az integráció fent idézett definíciójának (Dupcsik-Szabari 2015) figyelembe vételével a mi dezintegrációs fogalmunk a következő: olyan közösségi értékek és normakészletek együttese, amelyek rombolják, leépítik az integrációs szereplők kooperációját, csökkentik a társadalmi és az interperszonális interakcióban részt vevők összetartozásának érzését, és növelik a kommunikációs zavarok, valamint konfliktusok kialakulásának esélyét. A dezintegráció tehát nem egyenlő a szegénységgel és a depriválódással. Attól, hogy valaki szegény, még nem feltétlenül dezintegrált, de erre az empirikus bizonyítékok alapján jóval nagyobb az esélye.

Mi indokolja, hogy kutatásunkban ne elégedjünk meg a hagyományos egyenlőtlenség modellek használatával? Elsőként arra hívnánk fel a figyelmet, hogy a társadalmi újratermelés rendjében alapvető módosulások történtek. A redisztribúció jellege és társadalmi következményei, a piacon és a pénzforgalmon kívüli gazdasági 
és egyéb csereügyletek jellegzetességei, nagysága és arányai, réteg- és csoportképző hatásaik nagymértékben ismeretlenek. A piac, a gazdaság és a redisztribúciós rendszerek egymásba csúszása jelentős mértékú. A fejlesztési források döntő része (már 2005-ben több mint 70-80\%-a) a projektek redisztribúciós rendszerén keresztül jut el a piaci szereplőkhöz. A szociális juttatások jelentik az elsődleges megélhetési forrást legalább a társadalom harmada számára, és más csoportok esetében is jelentős lehet a szerepük. A politikai hatalomgyakorlók egyre növekvő mértékben és közvetlenül avatkoznak be a gazdaság múködésébe a fejlesztési források befolyásolt felosztása révén vagy például a közvetlen tőkejuttatásokkal, az önkormányzati/állami megrendelések politikai érdekeket szolgáló terítésével. A gazdasági szereplők racionális stratégiája, hogy a forrásfelosztást és a közszféra megrendeléseit egyre inkább az ellenőrzésük alá vonják. A politika a projektesítés előtt nem ismert módokon és szándékok miatt vonult be a gazdaságba, míg a gazdasági szereplők érdekei rendre átszövik a gazdaság szabályozására és a fejlesztési források szétosztására vonatkozó politikai cselekvéseket és döntéseket.

A fejlesztési források projektesített redisztribúciója az utóbbi évtizedekben általánossá vált a fejlesztés/ támogatás minden területén, így a közigazgatásban vagy a gazdasági üzletek világban is (Sjöblom 2006). A közigazgatásban a projekt alapú szervezés és fejlesztés gyakorlatának elterjedése mögött a közügyekbe történő beavatkozás mechanizmusainak legitimációs szándéka, a közfeladatok ellátásának kiszervezése, a sokasodó közigazgatási szintek összekapcsolásának igénye áll (Pierre-Peters 2000). A Boltanski és Chiapello (2005) szerzőpáros a kapitalizmus új szelleméről írt könyve szerint a globalizált korszak hálózati kapitalizmusának egyik legfőbb jellemzője, hogy az üzleti világban is a projektek horizontális hálózatai váltják fel a hierarchikus szervezettséget.

A projektesítésnek a nagy szociális és egyéb ellátórendszerekre, a munkaerőpiac múködésére és a gazdasághoz és közigazgatáshoz kapcsolódó hatalmi mező átrendeződésére gyakorolt hatásai áttételesen és közvetlenül is erőteljesen befolyásolják a társadalmi integrációs/dezintegrációt és egyenlőtlenségeket. A projektforrásokhoz való „hozzáférés” különbségei további társadalmi egyenlőtlenségekhez vezetnek a projektben történő részvétel, inklúzió és a projektekből történő exklúzió kutatói szerint (Sucksmith 2000). Az általános projektesítés új társadalmi újratermelési viszonyokat hoz létre (Kovách 2000, Ray 2001). Azok a társadalmi csoportok, területek, települések, amelyek tartósan kizáródnak a projektforrások felhasználásából, jelentős hátrányokat szenvednek el. A kiemelt projektek például nem járulnak hozzá a területi különbségek mérsékléséhez és eloszlásuk meglehetősen egyenetlen Magyarországon (Balogh 2009). A szegénység elleni projektek hatása időleges marad (Darvas-Ferge 2012a, 2012b). A projektforrások feletti rendelkezés megerősítheti egyes csoportok hatalmi helyzetét (Csurgó-Kovách 2015, Csurgó-Kovách-Kucerová 2008). A projektesítésnek közvetlen réteg- és csoportképző hatást is tulajdonítanak. A projektesítés az egyenlőtlen forrásfelosztás mellett elfedi a valós egyenlőtlenségeket és hozzájárul azok legitimálásához. A projektek megszerzésében, szervezésében és lebonyolításában kulcsszerepet játszó, intellektuális tőke és menedzseri tudás birtokában levő csoportok privilegizálják a projektek feletti rendelkezést, és ennek a következménye a projektosztály létrejötte (Andersson 2006, Kovách-Kucerova 2006, 2009, Kovách 2013). Csak nagyon kevéssé ismert tehát, hogy az újratermelés új rendje miként hat a megélhetési stratégiákra, a társadalmi réteg- és csoportképződésre. A legtöbbet a jövedelmi különbségek alakulásáról tudunk. Ezek utóbbi időkben jelzett növekedését az elemzők inkább a növekvő eladósodottságnak, az iskolázottság szerepváltozásának, a foglalkoztatottsági problémáknak és a redisztribúciós 
politikák változásának tulajdonítják, mint a gazdasági válság hatásának (d - Tóth 2012). Ez megerősíti azt a feltételezésünket, hogy a társadalmi újratermelésben nemcsak mennyiségi, hanem minőségi jellegú változások történtek, amelyek okait, hatásait nehezen lehet a foglalkozási besorolás alapján képzett csoportokkal kifejezni. Minden bizonnyal megnőtt például a prekárius, bizonytalan rétegződési helyzetbe kerülőknek az aránya, ami újabb adalék a társadalmi újratermelési rendszer teljes átalakulásának a felismeréséhez. Egyes tendenciák, (például a jövedelmi különbségek változása) megfelelőképpen mérhetőek egy egydimenziós modell felhasználásával, de az összetettebb folyamatok elemzése nem megoldott.

Másodszor: a rétegződés kérdéskörei az integráció kutatás szempontjából két vonatkozásban bírnak jelentőséggel. Elsőként: a „mi szerint rétegződik a magyar társadalom” kérdésre adott válasz arra is rámutat, hogy mi az integráció/dezintegráció egyik legfontosabb mechanizmusa vagy mechanizmusai. ${ }^{14}$ A rétegződés foglalkozási besorolást használó hagyományos paradigmája esetében munkaviszony alapú integrációs mechanizmusról beszélhetünk, és a kutatási kérdés ezen a szinten az, hogy mennyiben mondanak mást, újat az elmúlt évek kutatásai a munkaviszony (foglalkozási viszony) alapú integráció új elemzési szempontokkal történő bővíthetőségéről, bővítendőségéről illetve más integrációs mechanizmusok (például piac, redisztribúció) érvényességéről. Másodikként, az integráció/dezintegráció mértéke szerint elkülöníthető csoportok meghatározása és kutatása az a feladat, amelyet meg kell oldani az empirikus elemzés során és az empirikus elemzés céljaira. Ez utóbbi kutatási cél egyszerre jelenti a hagyományos rétegződés-csoportok képzését és a multi-dimenzionális szempontok alkalmazását. A társadalmi rétegződés kutatásának a társadalmi integrációval való összefüggésben az előbbiek értelmében kettős célja van:

1. a hagyományos rétegződési paradigma, valamint újabb (pl. fogyasztás, individualizáció) szempontok szerinti releváns rétegek, csoportok leírása és képzése, amelyek elkerülik az azonosíthatatlanság csapdáját;

2. azoknak az integrációs és dezintegrációs mechanizmusoknak a leírása és elemzése, amelyek magyarázzák a rétegek jellemzőit, illetve az egyes régeződés modellek különbségeit.

A kettős cél kivitelezése esetén olyan csoportosításokhoz juthatunk el, amelyeknek belső integráltságát, illetve a magukat a csoportokat létrehozó integrációs mechanizmusokat is leírhatjuk.

A társadalomtudósok a társadalmi dezintegráció kutatására még az integráció kutatásánál is kevesebb figyelmet fordítottak, helyesebben a dezintegrációt nagyon gyakran az integráció puszta negatív melléktermékének, kedvezőtlen kimenetelének, válságtermékének, elkerülendő elemének, röviden anómiának tételezik. Egyrészt a dezintegráció megközelíthető úgy, hogy arra a kérdésre keresi a választ:

a. „Mi feszíti szét a társadalmat?”,

b. másrészt, melyek azok a társadalmi mechanizmusok, struktúrák, amelyek nem az összetartást, nem az együttműködési készséget generálják, hanem annak ellenkezőjét.

c. végül pedig, milyen empirikusan elkülöníthető, vizsgálható részei, elemei vannak a dezintegratív folyamatoknak.

14 Integrációs mechanizmusnak a cselekvéseknek, beállítódásoknak, képzeteknek, stb. minden olyan ideáltipikus készletét tekintjük, amely adott integrációs ágensek kooperációjának szintjét javítja és/vagy fenntartja a kooperáció további lehetőségét (Dupcsik-Szabari 2015). 
A dezintegrációval kapcsolatosan azonban létezhet még egy szint vagy inkább megközelítés, amelyet úgy fogalmazhatnánk meg, hogy a dezintegráció mindig és minden formájában ellentéte, negatív aspektusa-e az integrációnak, vagy vannak olyan szituációk, legyenek azok politikai, társadalmi, gazdasági vagy kulturális jellegúek, amikor a dezintegrációnak, hosszú távon, inkább pozitív hatásai lehetnek (pl. Ferge Zsuzsát idézi Dupcsik -Szabari 2015). A dezintegráció tehát biztosan egyenlő-e a társadalmi integráció hiátusaival? Az anómia és az anómikus folyamatok gyakorisága az egyes társadalmakban és az egyes társadalmi struktúrákban nem azonos, vannak olyan társadalmak, ahol bizonyos társadalmi struktúrák a társadalomban élő egyes egyéneket jobban késztetik arra, hogy „....nonkonformista, ne pedig konformista magatartást tanúsítsanak” (Merton 1980: 340), mint mások. De mi történik akkor, amikor ez az anómikus „nonkonformizmus” lesz egy idő után a meghatározó társadalomszervező elv, „a” norma? Az integráció és a dezintegráció ugyanis ideáltipikus fogalmak, vagyis a valóságban abszolút integrált és teljesen dezintegrált társadalom nem létezik. A kérdés tehát, hogy a dezintegrációt és az integrációt felfoghatjuk-e úgy, mint egy koordinátarendszert, amelynek két végpontján a teljesen integrált, illetve a teljesen dezintegrált társadalom áll, és az egyes társadalmak valahol a kettő között helyezkednek el.

\section{ÖSSZEGZŐ MEGJEGYZÉSEK}

A tanulmányban a magyar társadalom példáján keresztül tekintettük át azokat a fogalmi elemeket, amelyek a társadalmi integráció és társadalmi egyenlőtlenségek/rétegződés összefüggéseire és különbségeire vonatkoznak. Integráció, dezintegráció és rétegződés egymást részben átfedő fogalmak, ugyanakkor az integráció elemzése és mérése új kutatási szempontok alkalmazását teszi szükségessé. Az integráció magában foglalja mindazt, amit a rétegződéskutatás és osztályelemzés tartalmi és metodológiai vonatkozásban elért, ugyanakkor a társadalom szereveződésének a megértéséhez, a „mi tartja össze a társadalmat”, „mitől múködik a társadalom" jellegú kérdésekre történő válaszkeresés új módszereket is igényel, amelyek lényegi elemei a teoretikus, kvantitatív és kvalitatív módszerek következetes, együttes és egymásra vonatkoztatott felhasználása és az újabb elemzési módszerek (pl. a hálózatelemzés mint kutatási technika, a kísérletek) alkalmazása.

Az egyenlőtlenségek kapcsán bemutattuk a legfontosabb dezintegrációs folyamatokat. Az iskolai, a jövedelmi egyenlőtlenségek, a depriváltság növekedése mögötti okok nehezen megérthetőek a tényszerű leírás és a mutatók elemzésének a szintjén maradva. A hatalmi rendszerek, a redisztribúciós rendszer sajátosságai, a normák és (fogyasztási) értékek, az individualizációs trendek társadalomszervező következményeinek új típusú megközelítése lehet az integráció/dezintegráció megértésének a kulcsa. Az új típusú megközelítés arra vonatkozik, hogy a magyar társadalom szerveződésében vagy éppen a társadalmi kooperáció töredeződésében meghatározó folyamatok következményeit nem a rétegződési szintek, osztályszerkezet egyes elemeihez rendelt mutatóként érdemes felfogni, hanem azok elemzéséből kiindulva szükséges a társadalom releváns csoportjainak feltérképezése. Ez a módszer segítheti egyrészt a társdalom valósabb tagolódósának a leírását, másrészt a társadalmi egyenlőtlenségeket létrehozó és fenntartó mechanizmusok megértését. A kutatás központi fogalmai között ezért kaptak különös hangsúlyt az integrációs mechanizmusok, amelyek szükségszerűen igénylik a társadalom valós tagozódásának (rétegződésének) a megújított elemzését, ugyanakkor lehetővé teszik a rendelkezésre álló elemzési technikák segítségével a társadalmi integráció/dezintegráció mint rendszer értelme- 
zését. A társadalmi rétegződés kutatása lényeges, és eddig többnyire elhanyagolt szempontokkal bővíthető így. $\mathrm{Az}$ integráció/dezintegráció múködését létrehozó és kondicionáló mechanizmusok jobb megismerése pedig mintegy a korábbi kutatásokban mechanikusnak értelmezett társadalmi struktúra kutatást felváltva a társadalom mozgástörvényeinek a jobb megértéshez vihet közelebb.

A tanulmány kutatási stratégiát is ajánl az integráció/dezintegráció és társadalmi egyenlőtlenségek kutatáshoz. A stratégia számol azzal, hogy a rétegződési szempontokkal is egybekapcsolódó elemzés mellett, a kutatási projekt többfajta kvalitatív és kvantitatív kutatást is indít a munkaerő-piac, a kapcsolatok, az intézmények, az értékek és normák, a hatalom és a területi integrációs és dezintegrációs témákról. A rétegződés és integráció altéma legfontosabb hozzájárulása a kutatási projekthez az új szempontok szerint is azonosítható csoportok, rétegek, osztályok leírása és képzése, valamint azoknak az integrációs/dezintegrációs mechanizmusoknak az elemzése, amelyek magyarázzák az ezek közötti különbségeket. 


\section{HIVATKOZÁSOK}

A KSH jelenti. Gazdaság és társadalom 2013. I-IV. negyedév. (2014) Budapest: KSH.

A KSH jelenti. Gazdaság és társadalom 2014. I-IV. negyedév. (2015a) Budapest: KSH.

A KSH jelenti: Gazdaság és társadalom, 2014/12. (2015b) Statisztikai Tükör 2015/17, február 27. Budapest: KSH.

Andersson, K. (2006) Pursuing innovations through projects - the paradox of project management as a tool for regional development. In Sjöblom, S. - Andersson, K. - Ecklund, E. - Godenhjelm, S. (szerk.) Project proliferation and governance. Helsinki: Helsinki University Press, 59-75.

Atkinson, W. (2010) Class, Individualization and Late Modernity: In Search of the Reflexive Worker. Basingstoke: Palgrave.

Balogh P. (2009) Kontraproduktivitás a fejlesztéspolitikában? A kiemelt projektek empirikus vizsgálata. Szociológiai Szemle (2), 79-102.

Beck, U. (1997) Túl renden és osztályon? In Angelusz R. (szerk.) A társadalmi rétegződés komponensei. Budapest: Új Mandátum, 418-464.

Boltanski, L. - Chiapello, E. (2005) The new spirit of capitalism. Verso Books.

Bonoli G. (2013) Az aktív munkaerő-piaci politika politikai gazdaságtana. Esély, 5, 15-37.

Bourdieu, P. (1984) Distinction. A Social Critique of the Judgement of Taste. Cambridge: Harvard University Press.

Bourdieu, P. (1999) Gazdasági tőke, kulturális tőke, társadalmi tőke. In Angelusz R. (szerk.) A társadalmi rétegződés komponensei. Budapest: Új Mandátum Könyvkiadó, 156-178.

Bukodi, E. (2006) Társadalmunk szerkezete különböző nézőpontokból. In Kovách I. (szerk.) Társadalmi metszetek. Budapest: Napvilág. 109-160.

Bukodi E. - Altorjai Sz. - Tallér A. (2005) A társadalmi rétegződés aspektusai. Budapest: KSH.

Bukodi, E.- Goldthorpe, J. (2012) Decomposing 'Social Origins': The Effects of Parents' Class, Status, and Education on the Educational Attainment of Their Children. European Sociological Review, 10. 1093. http://dx.doi.org/10.1093/esr/jcs079.

Crompton, R. (1993) Class and Stratification: an Introduction to Current Debates. Cambridge - Oxford: Polity Press.

Crompton R. (2008) Class and Stratification, 3rd ed. Cambridge: Polity Press.

Crompton, R. - Devine, F. - Savage M. - Scott, J. (szerk.) (2000) Renewing Class Analysis. Oxford - Malden: Blackwell Publishers.

Crompton, R. - Scott, J. (2000) Introduction: the State of Class Analysis. In Crompton, R. - Devine, F. - Savage, M. - Scott, J. (szerk.) Renewing Class Analysis. Oxford - Malden: Blackwell Publishers. 1-15.

Csite A. - Kovách I. - Kristóf L. (2006) Fogyasztói csoportok az ezredforduló Magyarországán. In Kovách I. (szerk.) Társadalmi metszetek. Budapest: Napvilág, 253-292.

Csurgó, B. - Kovách, I. - Kucerová, E. (2008) Knowledge, Power and Sustainability in Contemporary Rural Europe. Sociologia Ruralis, 3, July, 292-312.

Csurgó, B.- Kovách, I. The LEADER Programme in Hungary- Bottom-up Development with Top-down Control? In Granberg I. - Andersson, K. - Kovách I. (szerk.) Evaulating the European Approach to Rural Development: Grass-roots Experiences of the LEADER Programme. Surrey: Ashgate, 2015, 53-77. http://dx.doi.org/10.1111/j.1467-9523.2008.00461.x.

Darvas Á. - Ferge Zs. (2013a) Gyerekesély programok kistérségi alkalmazása- a gyakorlat dilemmái és tanulságai. In Czibere I . Kovách I. (szerk.) Fejlesztéspolitika, vidékfejlesztés. Debrecen: Debreceni Egyetemi Kiadó, 169-215.

Darvas Á. - Ferge Zs. (2013b) A gyerekprogram kistérségi szerveződése. In Czibere I. - Kovách I. (szerk.) Fejlesztéspolitika, vidékfejlesztés. Debrecen: Debreceni Egyetemi Kiadó, 248-273.

Devine, F. (1998) Class analysis and the stability of class relations. Sociology, 1, $23-42$. http://dx.doi.org/10.1177/0038038598032001003.

Devine, F. - Savage, M. (2000) Conclusion: renewing class analysis. In Crompton, R. - Devine, F. - Savage, M. - Scott, J. (eds.) Renewing Class Analysis. Oxford - Malden: Blackwell Publishers, 184-200.

Dupcsik Cs. - Szabari V. (2015) Elméleti bevezető az Integrációs és dezintegrációs folyamatok a magyar társadalomban című OTKA kutatáshoz. socio.hu, 3. http://dx.doi.org/10.18030/socio.hu.2015.3.44.

Employment rate 1992-2013. Eurostat. 2014. május 28. Elérhető: http://epp.eurostat.ec.europa.eu/tgm/refreshTableAction.do?tab=t able\&plugin $=1 \&$ pcode $=$ tsdec420\&language $=$ en .

Erikson, R. - Goldthorpe, J. - Portocarrero, L. (1979) Intergenerational class mobility in three Western European societies: England, France and Sweden. British Journal of Sociology, 30, 415-441. http://dx.doi.org/10.2307/589632. 
Erőss G. (2012) Iskolai (dez)integrációs paradoxonok - Expanzió, integráció, szegregáció a magyar közoktatásban a rendszerváltás óta. In Kovách I. - Dupcsik Cs. - P. Tóth T. - Takács J. (szerk.) Társadalmi integráció a jelenkori Magyarországon. Budapest: Argumentum - MTA TK Szociológiai Intézet, 243-261.

Esping-Andersen, G. (1993) Postindustrial class structures: An analytical framework. In Esping-Andersen, G. (szerk.) Changing Classes. London: Sage.

Esping-Andersen, G. (2006) Jövedelmi egyenlőtlenség és esélyegyenlőség. In Giddens, A. - Diamond, P. (szerk.) Írások az egyenlötlenségröl, az egyenlősdiről - és az új egyenlőségről. Budapest: Napvilág, 21-59.

Fábián Z. - Róbert P. - Szivós P. (1998) Anyagi-jóléti státuscsoportok társadalmi miliői. In Kolosi T. - Tóth I. Gy. - Vukovich Gy. (szerk.) Társadalmi riport 1998. Budapest: TÁRKI, 72-91.

Fábián Z. - Kolosi T. - Róbert P. (2000) Fogyasztás és életstílus. In Kolosi T. - Tóth I. Gy. - Vukovich Gy. (szerk.) Társadalmi riport 2000. Budapest: TÁRKI, 225-259.

Ferge Zs. (1990) Variációk a társadalmi integráció témájára. Esély, 1, 3-17.

Ferge Zs. (2005) Ellenálló egyenlőtlenségek. A mai egyenlőtlenségek természetrajzához. Esély, 4, 3-41.

Ferge Zs. (2007) Mi történik a szegényekkel? Esély, 4, 3-23.

Ferge Zs. (2008) Miért szokatlanul nagyok a magyarországi egyenlőtlenségek? Esély, 2, 3-14.

Ferge Zs. (2010) Társadalmi áramlatok és egyéni szerepek. Budapest: Napvilág.

Ferge Zs. (2002) Struktúra és egyenlőtlenségek a régi államszocializmusban és az újkapitalizmusban. Szociológiai Szemle, 2, 9-33.

Gábos A. - Szivós P. - Tátrai A. (2013) Szegénység és társadalmi kirekesztettség Magyarországon, 2000-2012. In Szívós P. - Tóth I. Gy. (szerk.) Egyenlötlenség és polarizálódás a magyar társadalomban. Tárki Monitor Jelentések 2012. Budapest: Tárki, 37-60.

Gazsó F. - Laki L. - Pitti Z. (2008) Társadalmi zárványok. Budapest: MTA Politikai Tudományok Intézete.

Gazsó F. - Laki L. (1999) Esélyek és orientációk - fiatalok az ezredfordulón. Budapest: Okker.

Gazsó F. - Laki L. (2004) Fiatalok az újkapitalizmusban. Budapest: Napvilág.

Hajdu G. (2012) Bizalom, normakövetés és társadalmi részvétel Magyarországon a rendszerváltás után. In Kovách I. - Dupcsik Cs. - P. Tóth T. - Takács J. (szerk.) Társadalmi integráció a jelenkori Magyarországon. Budapest: Argumentum - MTA TK Szociológiai Intézet, 45-62.

Hegedűs J. - Fekete M. (2014) Korai iskolaelhagyás és a kriminalitás kapcsolata, kezelésének lehetőségei. QALL- Végzettséget mindenkinek! Program. Elérhető: http://oktataskepzes.tka.hu/document.php?doc_name=Projektek/2013/QALL/a_korai_ iskolaelhagys_s_a_kriminalits_kapcsolata.pdf.

Hradil, S. (1995) Régi fogalmak és új struktúrák. Miliő-, szubkultúra és életstíluskutatás a 80-as években. In Andorka R. - Hradil, S. - Peschar, J. L. (szerk.) Társadalmi rétegződés. Budapest: Aula, 347-387.

Huszár Á. (2012) Osztályegyenlőtlenségek. Az egyenlőtlenségek ábrázolása Magyarországon. Szociológiai Szemle, 22(2): 4-26.

Huszár Á. (2013a) Foglalkozási osztályszerkezet (I.) - Elméletek, modellek. Statisztikai Szemle, 1, 31-56.

Huszár Á. (2013b) Foglalkozási osztályszerkezet (II.) - Az osztályozás problémái Statisztikai Szemle, 2, 117-131.

Huszár Á. (2013c) Foglalkozási osztályszerkezet (III.)- Egy normatív-funkcionalista osztálymodell vázlata. Statisztikai Szemle, 7, 718-744.

Ilonszki G. - Lengyel Gy. (2009) Válaszúton: Konszolidált vagy színlelt demokrácia? Politikatudományi Szemle, 1, 7-25.

Jelentés a közfoglalkoztatás és a hozzá kapcsolódó képzési programok támogatási rendszere hatékonyságának, eredményességének ellenőrzéséről. Budapest: Állami Számvevőszék 2013. szeptember.

Kapitány Á. - Kapitány G. (2012) A kultúra és az értékek szerepéről. In Kovách I. - Dupcsik Cs. - P. Tóth T. - Takács J. (szerk.) Társadalmi integráció a jelenkori Magyarországon. Budapest: Argumentum - MTA TK Szociológiai Intézet, 83-99.

Keller T. - Kolosi T. (2010) Kikristályosodó társadalomszerkezet, In Kolosi T. - Tóth I. Gy. (szerk.) Társadalmi riport 2010. Budapest: TÁRKI, 105-135.

Kertesi G. - Kézdi G. (2009) Általános iskolai szegregáció Magyarországon az ezredforduló után. Közgazdasági Szemle, november, 959-1000.

Kolosi T. (1987) Tagolt társadalom. Budapest: Gondolat.

Kolosi T. (2000) A terhes babapiskóta. A rendszerváltás társadalomszerkezete. Budapest: Osiris.

Kolosi T. - Keller T. (2012) Megéri tanulni...? Származás, iskola, foglalkozás, kereset - utak és elágazások a rendszerváltást követően. In Kolosi T. - Tóth I. Gy. (szerk.) Társadalmi riport 2012. Budapest: Tárki, 41-64. 
Koltai L. - Kulinyi M. (2013) A közfoglalkoztatást szervezők értékei. Esély, 5, 38-67.

Kovách I. - Kristóf L. (2012) Elit és társadalmi integráció. In Kovách I. - Dupcsik Cs. - P.Tóth T. - Takács J. (szerk.) Társadalmi integráció a jelenkori Magyarországon. Budapest: Argumentum - MTA TK Szociológiai Intézet, 30-44.

Kovách, I. (2000) LEADER, the new social order, and Central- and East-European countries. Sociologia Ruralis, 2, $181-190$. http://dx.doi.org/10.1111/1467-9523.00140.

Kovách I. (2013) A felemelkedő projektosztály. In Czibere I. - Kovách I. (szerk.) Fejlesztéspolitika, vidékfejlesztés. Debrecen: Debreceni Egyetemi Kiadó, 157-169.

Kovách, I. - Kucerova, E. (2006) The project class in Central Europe. The Hungarian and Czech cases. Sociologia Ruralis, 1, 3-21. http://dx.doi.org/10.1111/1467-9523.00143.

Kovách I. - Kuczi T. - Jókuthy E. (2006) Az osztályok, a társadalmi struktúra és rétegződés kutatásának állapotáról és megújitásának szükségességéről. In Kovách I. (szerk) Társadalmi metszetek. Budapest: Napvilág, 19-35.

Körösényi A. (2012) A politikai polarizáció és következményei a demokratikus elszámoltatásra. In Boda Zs. - Körösényi A. (szerk.) Trendek a magyar politikában. Budapest: MTA TK PTI.

Kuczi T. - Kovách I. - Kristóf L. (2006) A szociológia szerepváltozása és az értelmiség útja az osztályhatalomból. In Kovách I. (szerk.) Társadalmi metszetek. Érdekek és hatalmi viszonyok, individualizáció és egyenlötlenség a mai Magyarországon. Budapest: Napvilág, 79-158.

Ladányi J. - Szelényi I. (2004) Cigányok és szegények Magyarországon, Romániában és Bulgáriában. Szociológiai Szemle, 4, 72-94.

Laki L. (2009) A rendszerváltás avagy a „nagy átalakulás”. Budapest: Napvilág.

Laky T. (1996) A munkaeröpiac keresletét és kinálatát alakitó folyamatok. Budapest: Figyelő.

Lash S. - Urry J. (1997) The end of organized capitalism. University of Wisconsin Press.

Mártonfi Gy. (2013) Korai iskolaelhagyás a magyarországi szakképzésben. Observatory Centre for Educational Development. Elérhető: http://www.observatory.org.hu/wp-content/uploads/2013/09/ReferNet_2013_ESL_HU.pdf.

Mártonfi Gy. (2014) Korai iskolaelhagyás - Hullámzó trendek. Educatio, 1, 36-49.

McNail, S. - Levine, R. - Fantasia, R. (szerk.) (1991) Bringing Class Back. In Contemporary and Historical Perspectives Boulder. Boulder, Colorado: Westview Press.

Medgyesi M. - Tóth I. Gy. (2012) A jövedelmi egyenlőtlenségek hosszú távú meghatározói Magyarországon. In Kolosi T. - Tóth I. Gy. (szerk.) Társadalmi riport 2012. Budapest: Tárki. 144.

Medgyesi M. (2012) Egyenlőtlenségek iránti attitúdök Magyarországon. In Kolosi T. - Tóth I. Gy. (szerk.) Társadalmi riport 2012. Budapest: Tárki, 314-330.

Merton, R. K. (1980) Társadalomelmélet és társadalmi struktúra. Budapest: Gondolat.

Messing V. (2012) Kettévágott munkapiac, szétforgácsolt társadalom - Avagy hogyan dezintegrálják a magyar munkaerőpiacot és a társadalmat az állami foglalkoztatáspolitikai beavatkozások, különös tekintettel a közfoglalkoztatotti programokra. In Kovách I. - Dupcsik Cs. - P. Tóth T. - Takács J. (szerk.) Társadalmi integráció a jelenkori Magyarországon. Budapest: Argumentum - MTA TK Szociológiai Intézet, 204-221.

Miliband, E. (2006) Számít-e az egyenlőtlenség? In Giddens, A. - Diamond,P. (szerk.) Írások az egyenlötlenségről, az egyenlősdiröl - és az új egyenlöségröl. Budapest: Napvilág, 61-76.

Pierre, J . - Peters, B. G. (2000) Governance, Politics and the State. Political Analysis Series. London: MacMillan Press Ltd.

PISA2012. Összefoglaló jelentés. (2013) Budapest: Oktatási Hivatal.

Ray, Ch. (2001) Territorial co-operation between rural areas: elements of a political economy of EU rural development. Sociologia Ruralis, 3, 279-295. http://dx.doi.org/10.1111/1467-9523.00183.

Róbert P. - Albert F. - Dávid B. - Kristóf L. - Szabó A. (előkészületben) A magyar körte. A magyar társadalom osztályszerkezete.

Róbert P. (2013) Társadalmi rétegek, osztályok vizsgálata a 2011. évi népszámlálás adatain Statisztikai Szemle, 3, 314-319.

Savage M. - Warde, A. - Devine, F. (2005) Capitals, assets and resources: Some critical issues. British Journal of Sociology, 5, 31-48. http://dx.doi.org/10.1111/j.1468-4446.2005.00045.x.

Savage, M. - Devine, F - Cunningham, N. - Taylor, M. -Li, Y. - Hjellbrekke, J. - Le Roux, B. - Friedman, S. - Miles A. (2013) A New Model of Social Class: Findings from the BBC's Great British Class Survey Experiment. Sociology, 2, 219-250. http://dx.doi.org/10.1177/003803851348112.

Schulze, G. (1992) Die Erlebnisgesellschaft. Kultursoziologie der Gegenwart. Frankfurt am Main - New York: Campus Verlag. 
Sen, A. (2003) Társadalmi kirekesztés: Fogalom, alkalmazás és vizsgálat. Esély, 6. 3-22.

Shucksmith, M (2000) Endogenous Development, Social Capital and Social Inclusion: perspectives from leader in the UK. Sociologia Ruralis, Volume 40, Issue 2, 208-218. http://dx.doi.org/10.1111/1467-9523.00143.

Sjöblom, S. (2006) Towards a projectified public sector - project proliferation as a phenomenon. In Sjöblom, S. - Andersson, K. - Ecklund, E. - Godenhjelm, S. (szerk.) Project proliferation and governance. Helsinki: Helsinki University Press, 9-33.

Szabó A. (2012) A magyar egyetemisták és főiskolások társadalmi helyzete. In Szabó A. (szerk.) Racionálisan lázadó hallgatók 2012. Szeged: Belvedere Meridionale, 25-44.

Szabó A. (2013) A közfoglalkoztatás jelentősége két gazdasági recesszió tükrében. Esély, 4, 73-86.

Szalai J. (2012) A cigány gyerekek iskolai (le)értékeléséről. In Kovách I. - Dupcsik Cs. - P.Tóth T. - Takács J. (szerk.) Társadalmi integráció a jelenkori Magyarországon. Budapest: Argumentum - MTA TK Szociológiai Intézet, 275-293.

Szalai J. (2013) Az esélyegyenlőség esélytelensége: osztályozás és etnikai szelekció az általános iskolában. Esély, 2, 8-32.

Szívós P. - Tóth I. Gy. (szerk.) (2013) Egyenlőtlenség és polarizálódás a magyar társadalomban. Tárki Monitor Jelentések 2012. április. Budapest: Tárki.

Szívós P. - Tóth I. Gy. (szerk.) (2015) Jól nézünk ki (...?!) Háztartások helyzete a válság után. Tárki Monitor Jelentések 2014. március. Budapest: Tárki.

Utasi Á. (1984) Életstílus-csoportok, fogyasztási preferenciák. Budapest: Kossuth.

Walker R. (2006) Lehetőségek és életesélyek: a szegénység, az egyenlőtlenség és a kirekesztés dinamikái. In Giddens, A. - Diamond, P. (szerk.) Írások az egyenlötlenségről, az egyenlősdiről - és az új egyenlőségről. Budapest: Napvilág, 98-118. 